\title{
REVIEW:
}

\section{Indonesia's Efforts to Achive Globally Competitive Human Resources}

Dalam mempersiapakan diri menghadapi perkembangan revolusi industri 4.0 yang telah di mulai semenjak tahun 2011 yang lalu, Indonesia harus mulai mempersiapkan sumber daya manusianya untuk memenuhi kebutuhan akan sumber daya manusia yang berkompeten dalam menghadapi persaingan global yang semakin sengit. Dengan semakin berkembangnya revolusi industri 4.0, pekerjaan-pekerjaan yang ada saat ini akan menjadi semakin kompleks, bahkan memungkinkan untuk hilangnya beberapa pekerjaan yang ada saat ini dan digantikan dengan berbagai pekerjaan baru nantinya yang sesuai dengan perkembangan teknologi yang ada. Maka dari itu, setiap sumber daya manusia yang ada harus mempersiapkan diri dalam menghadapi persaingan yang akan datang dimana kita tidak hanya bersaing dengan sumber daya manusia yang berasal dari dalam negeri kita sendiri tetapi juga sumber daya manusia dari luar negeri. Persaingan global yang akan terjadi juga akan terjadi di antara perusahaan sehingga tentu saja setiap perusahaan akan membutuhkan sumber daya manusia yang kompetitif untuk membantu perusahaan dalam menghadapi persaingan di era ravolusi industri 4.0 saat ini.

Berdasarkan jurnal "Indonesia's Efforts to Achive Globally Competitive Human Resources", setiap pemimpin perusahaan yang ada di Indonesia memiliki peranan terpenting di dalam menciptakan sumber daya manusia yang dapat bersaing di dalam persaingan global. Hal ini dikarenakan, produktivitas perusahaan akan dicerminkan oleh produktivitas karyawannya (karyawan memiliki peranan yang sangat penting dalam keberhasilan suatu perusahaan) dan produktivitas setiap sumber daya manusia yang ada di dalam suatu perusahaan dipengaruhi oleh kepuasan sumber daya manusia itu sendiri terhadap setiap pemberian perusahaan seperti kompensasi dan gaji dari perusahaan (berbanding lurus), sehingga ketika perusahaan ingin dapat bersaing di dalam persaingan global perusahaan wajib juga untuk memiliki sumber daya manusia yang juga dapat besaing secara global. Maka dari itu, penting bagi perusahaan untuk melakukan seleksi sumber daya manusia yang akan bekerja di dalam perusahaan dengan memilih sumber daya manusia yang memiliki kompetensi yang sesuai dengan kebutuhan pekerjaan di dalam perusahaan saat ini. Yang kedua, perusahaan tetap perlu untuk memberikan pelatihan dan 


\section{Tugas Mata Kuliah Perekonomian Indonesia (KP E)}

pengembangan bagi setiap sumber daya manusia yang ada di dalam perusahaan agar setiap karyawan dapat terus mengikuti perkembangan pekerjaan yang ada saat ini dan tidak tertinggal dari perkembangan pengetahuan di bidang kerjanya. Perusahaan juga perlu untuk mempertahankan sumber daya manusia yang berkualitas yang ada di dalam perusahaan dengan memberikan motivasi dan inovasi bagi setiap karyawannya agar setiap sumber daya manusia yang ada di dalam perusahaan memberikan segenap kemampuan terbaik mereka dalam bekerja dan dapat membantu perusahaan di dalam menghadapi persaingan global yang semakin sengit ini. Dalam hal ini, penting sekali bagi perusahaan untuk memiliki budaya organisasi yang kuat yang diintegresikan ke seluruh anggota perusahaan untuk menjadi motivasi dan inovasi setiap sumber daya manusia yang ada di dalam perusahaan.

Pemegang peranan penting lainnya di dalam mempersiapkan sumber daya manusia yang kompetitif dalam mengahadapi persaingan global selain perusahaan yang seharusnya juga menjadi salah satu sorotan utama adalah pemerintah, terutama menteri pendidikan. Hal ini dikarenakan, sangatlah penting bagi calon pekerja untuk memiliki dasar pengetahuan yang mumpuni dan sesuai dengan yang kebutuhan zaman untuk memperoleh pekerjaan. Seperti yang telah disebutkan di dalam jurnal "Indonesia's Efforts to Achive Globally Competitive Human Resources" dan data yang diperoleh dari Badan Pusat Statistik Indonesia, pada tahun 2017 Indeks Pertumbuhan Manusia (IPM) Indonesia memang sudah tergolong tinggi, yaitu 70.81 (>70). Tetapi sayangnya masih ada 8 provinsi yang memiliki Indeks Pertumbuhan Manusia yang masih tergolong pada level rendah hingga menengah dan pada kenyataannnya masih banyak anak-anak pada usia sekolah (kurang lebih lima juta orang) tidak menempuh pendidikan formal, bahkan yang menempuh pendidikan formal pun hanya berfokus kepada nilai dan penghafalan teori di sekolah yang tidak menyiapkan mereka untuk menghadapi perubahan pada abad ke-21 dan revolusi industri 4.0. Ketakutan Indonesia untuk berubah dan merubah sistem pendidikan yang ada di Indonesia seringkali mengakibatkan sumber daya manusia di Indonesia kesulitan untuk bersaing dengan sumber daya manusia dari luar negeri. Maka dari itu, sangatlah penting peranan pemerintah untuk ikut campur tangan di dalam memberikan pembekalan sedini mungkin untuk setiap warga negaranya sehingga setiap warga negara indonesia dapat menjadi sumber daya manusia yang berkompeten dalam menghadapi perubahan lapangan kerja dan persaingan yang semakin sengit di dalam era 4.0. 


\section{Tugas Mata Kuliah Perekonomian Indonesia (KP E)}

Pada tahun 2018 yang lalu, Indeks Pertumbuhan Manusia (IPM) Indonesia mengalami kenaikan 0.58 dari Indeks Pertumbuhan Manusia pada tahun 2017 menjadi 71.39 dan 7 provinsi di Indonesia yang sebelumnya berada di level Indeks Pertumbuhan Manusia menengah, kini telah berstatus tinggi serta 1 provinsi di Indonesia yang sebelumnya memiliki Indeks Pertumbuhan Manusia level rendah, kini telah naik ke level menengah. Jika diperhatikan dari dimensi pengetahuan pada Indeks Pertumbuhan Manusia, terdapat dua indikator pembentuk IPM itu sendiri, yaitu Harapan Lama Sekolah dan Rata-rata Lama Sekolah penduduk usia 25 tahun ke atas yang mana terus mengalami peningkatan setiap tahunnya. Pada indikator pertama, yaitu Harapan Lama Sekolah mengalami peningkatan rata-rata sebesar 1.70 persen per tahun selama periode 2010 hingga 2018, dan pada tahun 2018, Harapan Lama Sekolah di Indonesia mencapai 12,91 tahun. Hal ini berarti semakin banyak masyarakat Indonesia yang bersekolah dan semakin besarnya peluang masyarakat untuk mengenyam pendidikan hingga lulus SMA atau D1. Pada indikator kedua, yaitu rata-rata lama sekolah penduduk usia 25 tahun keatas di Indonesia, telah mengalami peningkatan sebesar 1.14 persen per tahun selama periode 2010 hingga 2018 dan mencapai 8.17 tahun pada tahun 2018. Hal tersebut berarti, kualitas manusia Indonesia telah menjadi lebih baik setiap tahunnya dan bahkan rata-ata masyarakat Indonesia yang telah berusia 25 tahun ke atas telah menyelesaikan pendidikan hingga setidaknya kelas IX. Hal ini menunjukan peran aktif pemerintah di dalam mengusahakan pemerataan pendidikan sehingga masyarakatnya dapat menempuh pendidikan yang layak di sekolah formal. Usaha ini juga dapat di lihat secara nyata dari bagaimana kementrian pendidikan dan kebudayaan Indonesia mejalankan program Indonesia Pintar untuk menghindari anak putus sekolah. Pemerintah juga telah mulai memperhatikan kurikulum pendidikan di Indonesia dengan menerapkan kurikulum tahun 2013 semenjak tahun ajaran 2013/2014 yang memiliki empat aspek penilaian, yaitu aspek pengetahuan, aspek keterampilan, aspek sikap, dan perilaku yang tentunya sangat diperlukan dalam dunia kerja saat ini. Walaupun sampai saat ini, kurikulum tahun 2013 masih kurang disetujui oleh banyak golongan di dalam masyarakat, terutama para orang tua.

Pemeran terakhir menurut penulis yang tidak kalah pentingnya di dalam mendukung Indonesia untuk memiliki sumber daya manusia yang berkompeten dan dapat bersaing di dalam persaingan global saat ini ialah setiap pribadi atau sumber daya manusia itu sendiri. Untuk mencapai setiap harapan untuk menjadi sumber daya manusia yang bernilai di mata perusahaan dan yang dapat bersaing dengan sumber daya manusia yang lain baik dari dalam negeri maupun 


\section{Tugas Mata Kuliah Perekonomian Indonesia (KP E)}

yang berasal dari luar negeri, dibutuhkan keinginan dan motivasi diri dari setiap pribadi. Hal ini dikarenakan, tanpa adanya keinginan untuk menjadi yang lebih baik dibandingkan yang lainnya, tanpa ada keinginan untuk belajar dan mengembangkan diri sehingga dapat bersaing dengan yang lainnya maka setiap usaha yang diupayakan oleh pemerintah Indonesia dan setiap pemimpin perusahaan tidak akan bisa memberikan hasil yang maksimal dalam mengembangkan potensi sumber daya manusia yang ada di Indonesia.

\section{Penulis:}

1. Stephany Gunawan (130318106)

2. Geofanny natadika (130217375)

3. Kevin Eka Adriawan (130217356)

4. Alvin Lius Chandra (130317119)

5. Andri Monoarfa (130217235)

6. Nindy Safitri Indah (130118055)

7. David syaifuddin (130217383)

8. Muhammad Nasrullah (130118054)

\section{Sumber:}

Tayibnapis, Ahmad Zafrullah and Wuryaningsih, Lucia Endang and Gora, Radita (2018) Indonesia's Efforts to Achieve Globally Competitive Human Resources. International Journal of Humanities and Social Science Invention (IJHSSI), 7 (8). 0106. ISSN (Online): 2319 - 7722, ISSN (Print): 2319 - 7714

BPS. 2019. Pada tahun 2018, Indeks Pembangunan Manusia (IPM) Indonesia mencapai 71,39. https://www.bps.go.id/pressrelease/2019/04/15/1557/pada-tahun-2018--indeks-pembangunanmanusia--ipm--indonesia-mencapai-71-39.html. (akses 25 Agustus 2019) 
Kemendikbud. 2019. Program Indonesia pintar wujudkan pemerataan pendidikan nasional. https://www.kemdikbud.go.id/main/blog/2019/02/program-indonesia-pintar-wujudkanpemerataan-pendidikan-nasional. (akses: 25 Agustus 2019) 